\title{
Distribution and spread of the invasive slug Arion vulgaris Moquin- Tandon in Norway
}

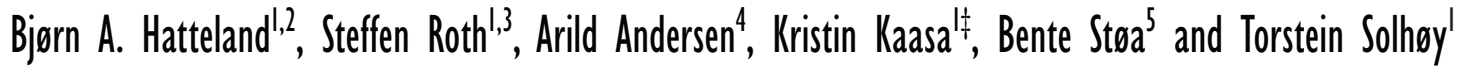

Hatteland BA, Roth S, Andersen A, Kaasa K, Støa B and Solhøy T. 2013. Distribution and spread of the invasive slug Arion vulgaris Moquin-Tandon in Norway. Fauna norvegica 32: 13-26.

The present distribution of the invasive slug Arion vulgaris Moquin-Tandon was studied in Norway. This important pest species has spread to many parts of Europe during the last decades, inflicting damage to agriculture and domestic gardens. It was first recorded in Norway in 1988, and has since spread to many parts of the country and is now recorded in 192 municipalities. We surveyed the current distribution by sampling and gathering species records in cooperation with garden societies and local authorities. Based on these records, we present distributional data as well as relative predictions of future distributions based on geoclimatic parameters. Currently, A. vulgaris covers most of coastal southern Norway while it shows a patchy distribution in northern Norway, recorded as far north as Finnsnes in Troms County.

doi: 10.5324/fn.v31i0.1473. Received: 2012-03-30. Accepted: 2012-10-18.

Published on paper and online: 2013-02-13.

Keywords: Arionidae, ArcGIS, invasive species, climate, Maxent analysis

1. Department of Biology, University of Bergen, P.O. Box 7800, 5020 Bergen, Norway

2. Horticulture and Urban Greening, Bioforsk Ullensvang - Norwegian Institute for Agricultural and Environmental Research, 5781 Lofthus, Norway

3. Natural History Collections, University Museum in Bergen, P.O. Box 7800, 5020 Bergen, Norway

4. Plant Health and Plant Protection Division, Bioforsk - Norwegian Institute for Agricultural and Environmental Research, Høgskoleveien 7, 1432 Ås, Norway

5. GEco - Geo-Ecological Research Group, Natural History Museum, University of Oslo, Oslo, Norway

\#. Present address: Bjerregaardsgate 30C, 0172 Oslo

Corresponding author: Bjørn Arild Hatteland

E-mail: bjorn.hatteland@bio.uib.no

\section{INTRODUCTION}

Invasive species are a global problem leading to economic losses and negative effects on natural ecosystems (Sax et al. 2005; Davis 2009). Knowing the current distribution as well as the potential distribution of invasive species is fundamentally important to determine the extent of today's as well as future problems related to such species. Modelling methods have recently been used to make predictions about future distributions of invasive species by combining data on biogeography and explanatory variables related to climate (Ward 2007; Nori et al. 2011). Based on such analyses we can indicate the potential distribution by presenting maps containing information on where conditions are favourable or not for the studied species. This has fundamental implications for future effects on crops and/or native biota, and hence is a crucial tool for management of such species.

The invasive slug Arion vulgaris (Moquin-Tandon, 1855) (in most of the literature up to now referred to as A. lusitanicus 1868 (Anderson 2005; Quinteiro et al. 2005)) has spread to many parts of Europe, including Scandinavia, during the last few decades (Reischütz 1984; Davies 1987; von Proschwitz 1992; Kaiser et al. 1993; Dolmen \& Winge 1997; Kozlowski and Kozlowski 
2011). It has been referred to as the Iberian or Lusitanian slug due to its assumed native distribution in the Iberian Peninsula. Arion vulgaris was first recorded in Norway in 1988 at three different localities; Langesund and Kråkerøy in eastern Norway and Molde in western Norway (von Proschwitz \& Winge 1994). It has been hypothesised that these introductions all originated from one shipment from the Netherlands to various garden centres (Solhøy, T. unpublished). Through the 1990s and 2000s A. vulgaris has become locally very abundant, in particular along the western coast (Dirks 2003; Tomasgård 2005) and the south-east of Norway (pers. obs.). Considerable damage caused by A. vulgaris has been reported from domestic gardens, vegetables, strawberry cultures and cereal fields (Frank 1998a, b; Grimm et al. 2000; Hofsvang 2003; Kaluski et al. 2005). In addition, $A$. vulgaris seems to have a negative effect on native slug species like Arion ater L.; A. ater seemingly disappears following invasion of an area by A. vulgaris (Davies 1987; von Proschwitz 1997). It is currently unknown if this is due to competition (e.g. food, shelter), egg predation or other factors such as introgression since these species may hybridise.

The pest nature of this slug has been explained by a high reproductive and survival rate, catholic feeding habits, sticky mucus, and large body size (von Proschwitz 1992; Kozlowski 2007). In addition, it has been hypothesised that A. vulgaris lacks natural enemies, or at least has fewer enemies (von Proschwitz \& Winge 1994; von Proschwitz 2008), although recent studies have shown that native beetles are significant predators of A. vulgaris (Hatteland 2010; Hatteland et al. 2010, 2011). According to published information and field observations (e.g. Kozlowski, 2007; Hatteland et al., pers. obs.) this species follows an annual life cycle, although some individuals live for two years (Davies 1987; Dirks 2003). Most of the adults die after egg lying in early or mid-autumn. Eggs hatch in late autumn, overwinter as juveniles and mature in the following late spring and summer.

We outline the recorded present distribution of this notable pest species in Norway. Our survey is compared thoroughly with a previous study published by Dolmen \& Winge in 1997. We also present a potential future distribution of $A$. vulgaris in Norway based on the current survey and modelling analyses using geoclimatic parameters such as average monthly temperature and precipitation.

\section{MATERIAL AND METHODS}

\section{Data collection}

Slugs have been collected and observed during various field surveys in Norway between 1995 and 2012, but mainly from 2006 to 2011. This has often been done in cooperation with garden societies, private gardeners and farmers, local newspapers, the Norwegian Food Safety Authority (Mattilsynet), and local agencies of agriculture and nature conservation at municipality and county levels (respectively "kommune" and "fylke" in
Norwegian). Rural areas in particular, including gardens, wasteland, road sides, and agricultural areas, were investigated. Slugs were collected alive, killed and stored at $-20{ }^{\circ} \mathrm{C}$ and identified by dissection of genitalia according to previous work (e.g. Noble 1992). If morphological identification was uncertain, mitochondrial DNA was analysed using the general invertebrate primers of Folmer et al. (1994) and the speciesspecific primers of Hatteland et al. (2011). In cases where samples of slugs were difficult to get, we obtained pictures of slugs from gardeners. If the quality was good enough and the colour variety of the slug (brown, reddish brown) clearly suggested $A$. vulgaris the information was considered as an approved record. We also received records from various sources (mainly local garden societies) reporting either high densities of slugs or single records of potential A. vulgaris specimens, which have not yet been confirmed. The former reports were given a status of "probable" while the latter were given a status of "uncertain" (Appendix 1). In the map of current distribution (Figure 1) we have combined these two categories.

\section{Recorded distribution}

The distribution was recorded per municipality and maps were produced in ArcGIS Desktop software version 9.3.1 (ESRI, 2003). A base map data-set of municipalities of Norway was provided by NorgeDigitalt (norgedigitalt.no). The distribution records of Dolmen \& Winge (1997) were added to the map.

\section{Distribution modelling}

The occurrence data were georeferenced using the free software Norgeskart (http://www.norgeskart.no) made by Statens kartverk. Only confirmed records were included, while uncertain and potential records were left out. This resulted in 219 occurrence points used for further analyses. When a record lacked information about the exact locality, the most probable locality within the municipality was chosen (e.g. largest town or village situated on the coast). All the georeferenced occurrence points were imported into ArcGIS along with two environmental predictor variables, covering all of Norway with a $1 \mathrm{x} 1 \mathrm{~km}$ resolution. These variables (PCA1 and PCA2) are based on a Principal Component Analysis (PCA) with 54 geoclimatic variables performed by Bakkestuen et al. (2008). PCA1 is a step-less oceanity gradient, which maximally fits the division of Norway into vegetation sections and reflects mostly precipitation related variables. PCA2 is a step-less temperature gradient, which maximally fits the division of Norway into vegetation zones by relating to mean temperatures mainly from June, July and August as well as elevation (Moen 1998). Because the resolution of the two environmental predictors is as coarse as $1 \mathrm{x} 1 \mathrm{~km}$, no environmental data were available for grid cells in coastal areas with a centre point falling in the sea. An occurrence point in such a grid cell was hence moved inland to the nearest grid cell supplied with environmental information if this grid cell was not situated more than $1 \mathrm{~km}$ away from the coast. 
A species distribution model was generated by applying the machine-learning method Maxent (Philips et al. 2006), which uses presence-only data to make predictions of species distributions. Maxent is a statistical method that finds the probability distribution of maximum entropy (i.e. that is most spread out, or closest to uniform) subject to the constraints given by our data (gridded presence records for a species, and predictor variables recorded for each cell in a common grid (Elith et al. 2006; Phillips et al. 2006)). Default settings were applied, but the replicated run type was set to cross-validation with ten replicates, i.e. the dataset was divided ten-fold and each fold was used in turn to cross-validate the model. The goodness-of-fit measure AUC (area under the ROC-curve $(\mathrm{ROC}=$ receiver operating characteristic) ) was used to evaluate the model (Fielding \& Bell 1997; Phillips et al. 2006). This is a non-parametric statistic that measures the model's ability to discriminate between a presence and a random background point. At values higher than 0.5 the model performs better than random. Values of 0.9-1 mean that the model's ability to discriminate between presences and background points is excellent.

\section{RESULIS}

Arion vulgaris was recorded in all the 19 counties of Norway, except the northernmost county of Finnmark. Furthermore, it is currently recorded in 192 of the 429 municipalities in Norway, of which 34 were already mentioned by Dolmen \& Winge (1997) (Appendix 1). In addition, the species has been recorded in 14 other municipalities by local garden societies, but has not been confirmed by the authors. There are also uncertain records from a further 9 municipalities, both from Dolmen $\&$ Winge (1997) and other sources (Appendix 2). The current distribution covers most of coastal southern Norway, while it is more scattered in northern Norway (Figure 1). The species has also been recorded in the inner fjord areas of western Norway as well as the lowlands of eastern Norway. Arion vulgaris has not been recorded at altitudes higher than $400 \mathrm{~m}$. a. s. 1., nor in the most continental parts of Norway, except some localities in eastern Norway such as Gjøvik and Raufoss in the county of Oppland (Figure 2). Furthermore, all records have come from anthropogenic habitats (e.g. gardens, parks), or seminatural woodlands within close proximity to such habitats. Arion vulgaris has typically been found in suburban areas and especially in transition zones from meadow/grassland or deciduous/mixed woodland to gardens, roads, parks or other open habitats.

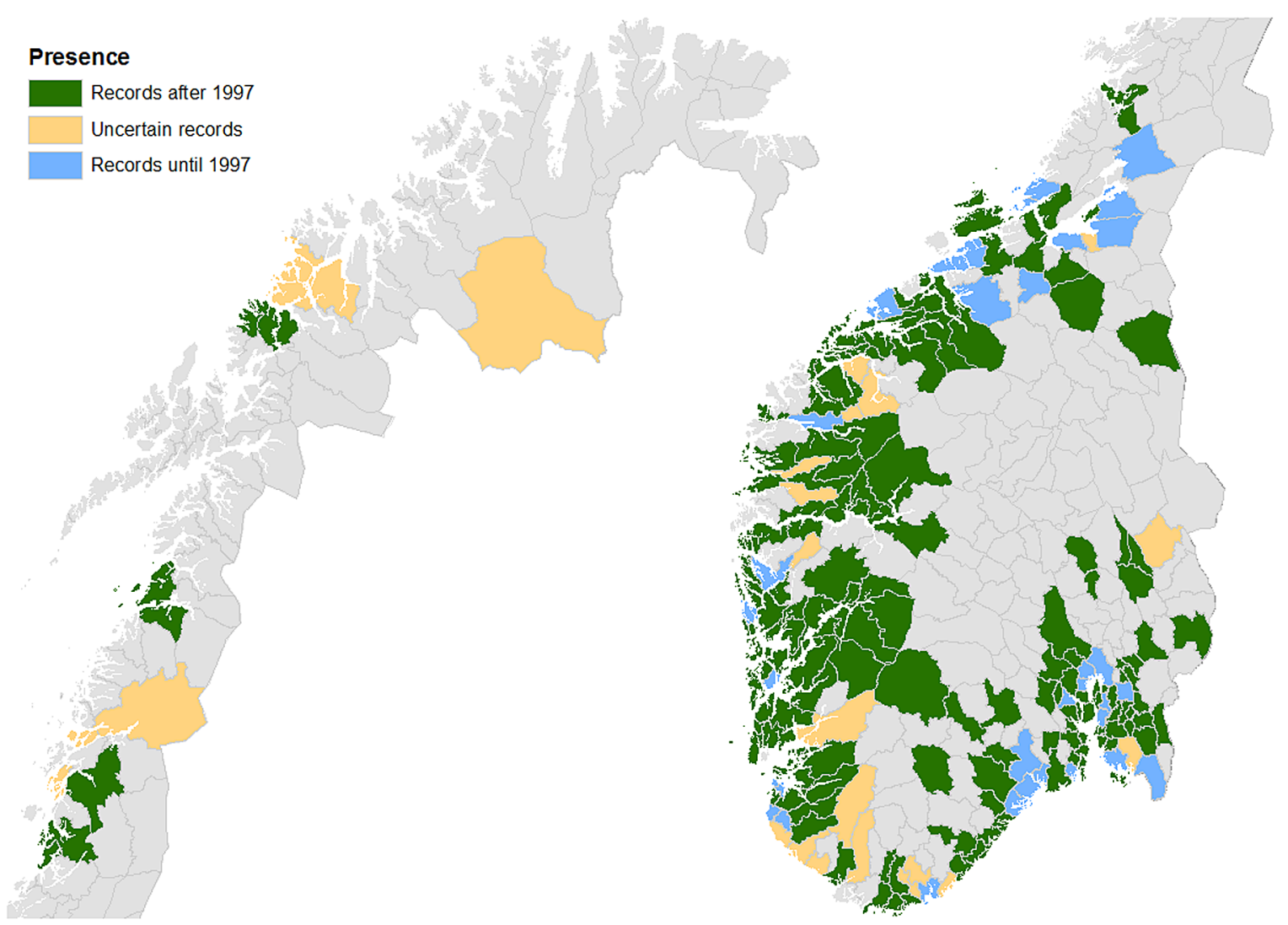

Figure I. Distribution of Arion vulgaris in Norway municipalitywise. Records before 1997 are taken from Dolmen \& Winge (1997). 


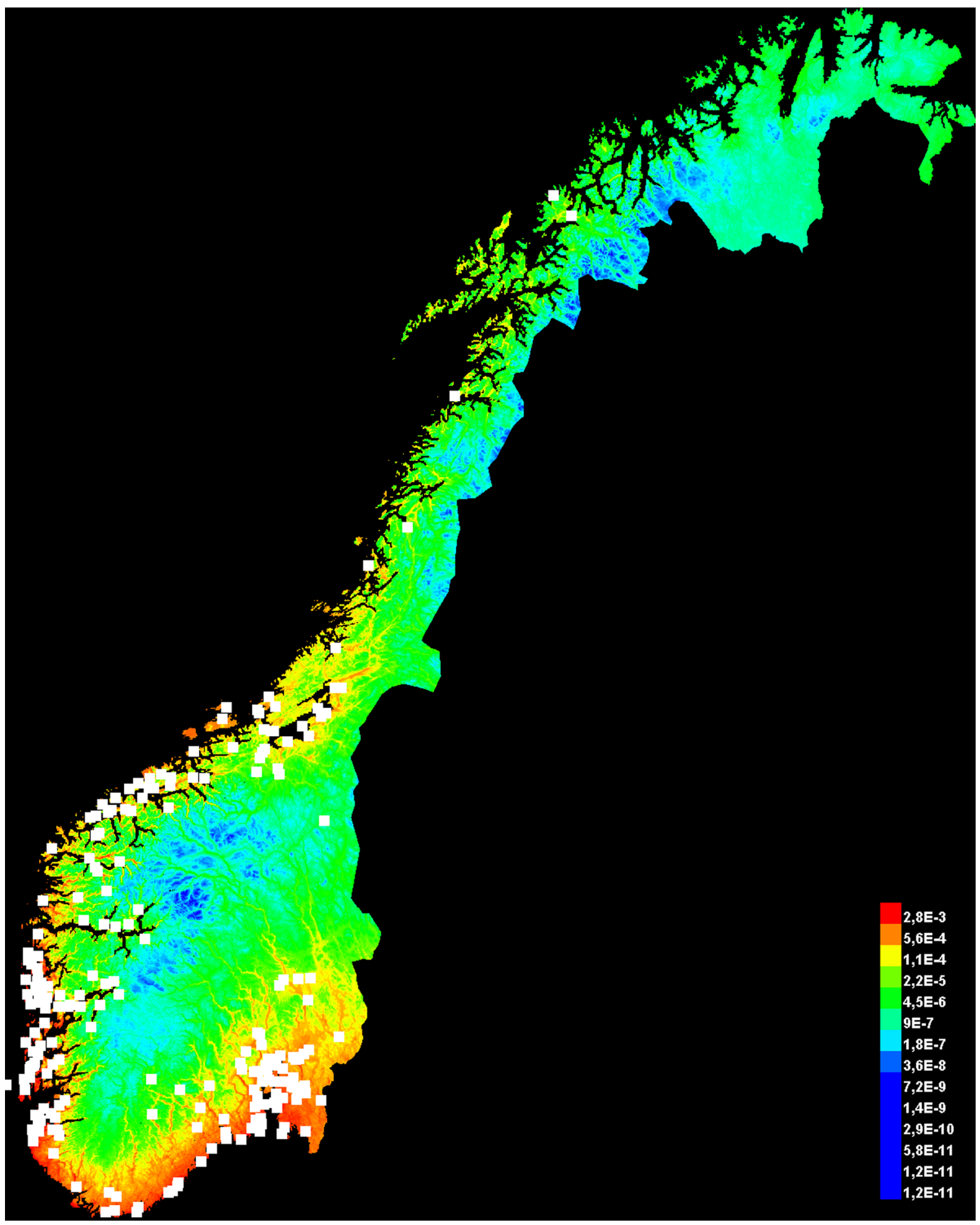

Figure 2. Habitat suitability map of Arion vulgaris in Norway using the raw output of Maxent with an exponential scale. White squares indicate the localities where the species has been recorded. Red to orange colours = high relative probability of occurrence, green to blue colours $=$ low relative probability of occurrence. 


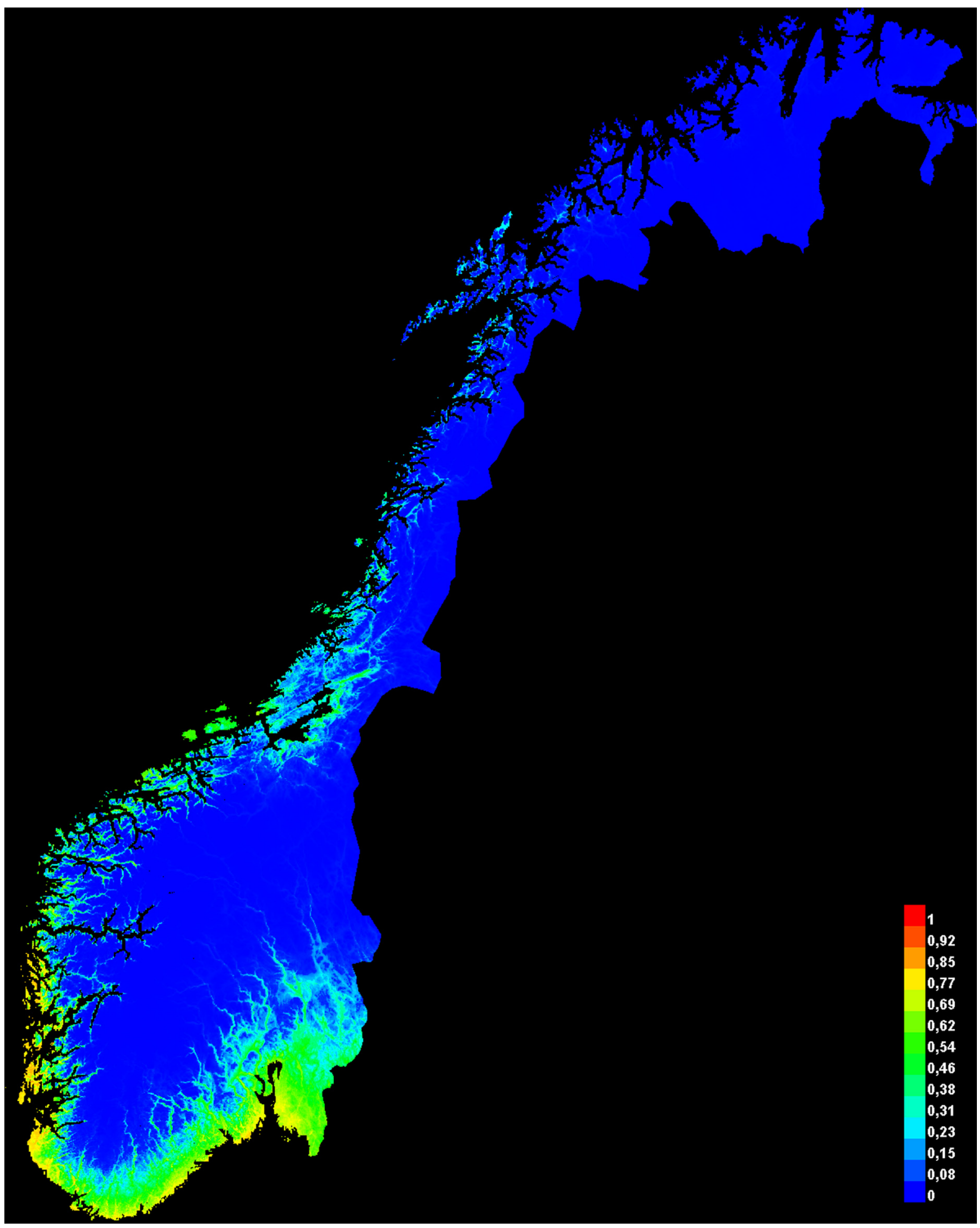

Figure 3. Habitat suitability map of Arion vulgaris in Norway with colours indicating the probability values of finding the species in the field based on Maxent analysis. The values given are on a logarithmic scale. 
The modelling analyses of a potential distribution based on climatic variables indicate that $A$. vulgaris may occur in all vegetation zones of Norway except the alpine and subalpine zones (Figure 2). The ranking of sites for habitat suitability was based on the 219 sites where the species has been recorded and gives a high probability of finding the species along the entire coast as far north as Vesterålen (Figure 3). Our analyses also suggest a high probability of finding the species in south-east Norway, which also reflects the recorded distribution (Figures 2 \& 3). The mean model goodness-of-fit (AUC) statistic for the ten predictions was 0.936 , which indicates that the discrimination between presence and background points was excellent. The contribution of axis PCA2 (temperature-related variables) contributed $99.5 \%$ while the axis PCA1 (precipitation-related variables) contributed only $0.5 \%$.

\section{DISCUSSION}

The main finding of this study is that the invasive A. vulgaris is currently distributed along most of the Norwegian coast from the Oslo Fjord up to Steinkjer in Nord-Trøndelag County. The slug has also been recorded further north, but these records are more scattered. However, A. vulgaris has occurred at high densities in recent years both in Bodø in Nordland County and in the northernmost locality at Finnsnes in Troms County. Our modelling analysis based on climatic parameters suggests that A. vulgaris may potentially be present along the entire coast of Norway up to Vesterålen in Nordland County at some point in the future.

The distribution recorded by Dolmen \& Winge (1997) mainly covered central Norway and south-east Norway, with only scattered recordings in western Norway. It is difficult to conclude if our records of a wide distribution in western Norway is due to an expansion after the study of Dolmen \& Winge (1997) or if the slug was actually already present in many of these areas but went undetected. Arion vulgaris is clearly favoured by the mild and wet Atlantic climate of the western coast when looking at today's distribution (Figure 1). Furthermore, the damage related to A. vulgaris reported in gardens and horticulture (e.g. strawberries) has been especially pronounced in coastal areas. These areas were, however, given more attention in the present survey and this may have led to some sampling bias towards coastal areas. Moreover, larger densities may increase the probability of finding the species in a given area.

The high dispersal capacity (see below) of this pest species makes it difficult to achieve an accurate impression of the distribution of established populations. It is not clear if the species actually has established in all of the localities presented in this study. Single records might only reveal spreading of this species in the year of sampling and we do not know if it will be found the following years. Observations suggest that $A$. vulgaris follows a typical pattern of an invasive species with an explosion in density a few years after being introduced into a new area, followed by a stabilisation period when density flattens out (Shigesada \& Kawasaki 1997; Arim et al. 2006).

Arion vulgaris seems to be mainly restricted to cultural habitats and semi-natural habitats. It has rarely been recorded in areas outside suburban and urban areas, not even in rural areas next to well-established populations (Hatteland, pers. obs.). The same pattern has also been found in other countries (Kozlowski \& Kozlowski 2011). However, it seems to have established populations in a few deciduous forests in Sweden (von Proschwitz, T., pers. comm.) and possibly in Norway (pers. obs.)

The presence-only method used in this study to model potential distributions has several benefits and drawbacks, but is regarded as an appropriate method when studying the fundamental niche of a species (Phillips et al. 2006; Ward 2007). Presence-only based methods are especially suited for data from museums and herbaria, but also for cryptic species where it is difficult to obtain absence data. Furthermore, machine-learning methods such as Maxent have been found to outperform more established methods (Elith et al. 2006), although options are more limited and power for statistical evaluation of predictive performance is lower compared to presence-absence based methods. Nonetheless, when studying potential distributions this has been argued to be the approach to use (Elith et al. 2006), especially when studying invasive species since various factors (e.g. dispersal limitations, historical restrictions) are often limiting the realised niche (Ward 2007). However, absence data are needed to adequately predict the existence of a species, although such data are dependent on systematic sampling designs so that the probability of false absences is low. Presence-only methods, like Maxent, may also suffer from bias in sampling effort (Elith et al. 2011). In our study, some regions of Norway have been sampled more intensively than others while sampling in several regions, especially northern Norway, has been limited.

Our modelling analyses suggest that A. vulgaris may have a potential distribution in the future covering the entire coastline up to Vesterålen in Nordland County. Average summer temperature and elevation seem to be the most important factors according to the results of the principal component method applied in this study. Furthermore, the vegetation zones in Norway seem to reflect the current distribution of $A$. vulgaris. The probability of finding the species in the nemoral and south boreal zone is high and only the alpine and subalpine zone seem to be unsuitable for this invasive slug. It has to be kept in mind that our analysis is based on a $1 \times 1 \mathrm{~km}$ grid scale. It can be expected that habitat structure and its resulting micro-climate may be more important for the establishment of A. vulgaris populations, and thus overrule the importance of climate conditions represented in our broader scale analysis. In that respect, our results that show a probability of only $60-85 \%$ of finding $A$. vulgaris even in such areas where the species is nowadays well established (see Figure 3) indicate that 
the species finds suitable climatic conditions on a local scale. Moreover, we found that precipitation-related variables are marginal for the recent distribution in Norway. Thus, regardless of regional differences, precipitation throughout the whole country (probably sufficient rain in the vegetation season and sufficient snow cover on relatively cold hibernation sites) is not a limiting factor for $A$. vulgaris: a picture that might differ from its European distribution, including its putative origin area.

Factors other than climate are important when it comes to geographic distributions of species. Dispersal abilities are, for instance, important to take into consideration when studying introduced species. Arion vulgaris has been observed to spread with cargo and cars in addition to the more obvious spreading vectors such as plant material and soil. Thus its potential distribution could be highly dependent on anthropogenic habitats and activity. The modelling analyses from our current study hypothesise that large parts of coastal and lowland Norway will be potentially suitable areas for this important pest species and hence management strategies should be aiming to limit further expansion.

Our study summarises the current distribution of this notorious invasive slug species in Norway and portrays a potential future distribution based on climate. Thus our study may be regarded as a baseline for future studies in terms of both sampling surveys and modelling analyses. Future work should also address questions regarding which variables are the most important in explaining the distribution outlined in this study and hence give a more accurate understanding of the factors that allow this invasive species to spread.

\section{ACKNOWLEDGMENTS}

We thank local garden societies, private gardeners, local newspapers, the Norwegian Food Safety Authority (Mattilsynet) and local departments of agriculture and nature conservation for their cooperation. We also thank John Skartveit, Stine Beate Balevik and Thomas Hornick for assisting in recording and collecting slugs. Furthermore, we are grateful to Rune Halvorsen and Vegar Bakkestuen for help with the modelling analyses. Finally we thank Trond Rafoss for making the map of current distribution. This study was partly funded by the University of Bergen and the Norwegian Research Council (project 803194).

\section{REFERENCES}

Anderson R. 2005. An annotated list of the non-marine Mollusca of Britain and Ireland. Journal of Conchology 38: 607-637.

Arim M., Abades S. R., Neill P. E., Lima M., Marquet P. A. 2006. Spread dynamics of invasive species. Proceedings of the National Academy of Sciences of the United States of America 103: 374-378.
Bakkestuen V., Erikstad L., Halvorsen R. 2008. Step-less models for regional environmental variation in Norway. Journal of Biogeography 35: 1906-1922.

Davies S. M. 1987. Arion flagellus Collinge and A. lusitanicus Mabille in the British Isles: a morphological, biological and taxonomical investigation. Journal of Conchology 32: 339-354.

Davis M. A. 2009. Invasion biology. Oxford University Press, Oxford.

Dirks I. 2003. Populationsdynamik und nahrungsprärefenz der Wegschnecke Arion lusitanicus in Norwegen. Unpublished Diplom thesis. Georg-August-Universität Göttingen, Göttingen, Germany.

Dolmen D., Winge K. 1997. Boasneglen (Limax maximus) og iberiasneglen (Arion lusitanicus) i Norge; utbredelse, spredning og skadevirkninger. "Limax maximus and Arion lusitanicus in Norway: distribution, expansion and injurious effects." Report 4: 4-24. Vitenskapsmuseet, Trondheim, Norway.

Elith J., Phillips S. J., Hastie T., Dudík M., Chee Y. E., Yates C. J. 2011. A statistical explanation of MaxEnt for ecologists. Diversity and Distributions 17: 43-57.

Elith J., Graham C. H., Anderson R. P., Dudík M., Ferrier S., Guisan A., Hijmans R. J., Huettmann F., Leathwick J. R., Lehmann A., Li J., Lohmann L. G., Loiselle B. A., Manion G., Moritz C., Nakamura M., Nakazawa Y., McC. J., Overton M., Townsend Peterson A., Phillips S. J., Richardson K., ScachettiPereira R., Schapire R. E., Soberón J., Williams S., Wisz M. S., Zimmermann N. E. 2006. Novel methods improve prediction of species' distributions from occurrence data. Ecography 29: 129-151.

ESRI 2003. ArcGis 9 - Environmental Systems Research Institute, Inc, Redlands, California. <http://esri.com/arcgis>.

Fielding A. H., Bell J. F. 1997. A review of methods for the assessment of prediction errors in conservation presence/ absence models. Environmental Conservation 24: 38-49.

Folmer O., Black M., Hoeh W., Lutz R., Vrijenhoek R. 1994. DNA primers for amplification of mitochondrial cytochrome c oxidase subunit I from diverse metazoan invertebrates. Molecular Marine Biology and Biotechnology 3: 294-299.

Frank T. 1998a. Slug damage and number of slugs (Gastropoda: Pulmonata) in winter wheat in fields with sown wildflower strips. Journal of Molluscan Studies 64: 319-328.

Frank T. 1998b. Slug damage and numbers of slug pests, Arion lusitanicus and Deroceras reticulatum, in oilseed rape grown beside sown wildflower strips. Agriculture, Ecosystems and Environment 67: 67-78.

Grimm B., Paill W., Kaiser H. 2000. Daily activities of the pest slug Arion lusitanicus. Journal of Molluscan Studies 66: 125-130.

Hatteland B. A. 2010. Predation by carabid beetles (Coleoptera, Carabidae) on the invasive Iberian slug Arion lusitanicus. $\mathrm{PhD}$ thesis. University of Bergen, Bergen.

Hatteland B. A., Grutle K., Mong C. E., Skartveit J., Symondson W. O. C., Solhøy T. 2010. Predation by beetles (Carabidae, Staphylinidae) on eggs and juveniles of the Iberian slug Arion lusitanicus in the laboratory. Bulletin of Entomological Research 100: 559-567.

Hatteland B. A., Symondson W. O. C., King R. A., Skage M., Schander C.. Solhøy T. 2011. Molecular analysis of predation by carabid beetles (Carabidae) on the invasive Iberian slug Arion lusitanicus. Bulletin of Entomological Research 101: 675-686. 
Hofsvang T. 2003. Snegler som skadedyr på planter. "Slugs as plant pests". Grønn kunnskap 7: 1-10.

KaiserH., GeiersbergerU., GrimmB.,PaillW. 1993.Untersuchungen über die biologischen und ökologischen Voraussetzungen des Massenauftretens der Spanischen Wegschnecke, Final Report, University of Graz, Austria.

Kaluski T., Kozlowski J., Kozlowska M. 2005. Evaluation of damage to seeds and seedlings of different winter wheat cultivars caused by Deroceras reticulatum (Müller, 1774) and Arion lusitanicus Mabille, 1868 in laboratory conditions. Folia Malacologica 13: 189-195.

Kozlowski J. 2007. The distribution, biology, population dynamics and harmfulness of Arion lusitanicus Mabille, 1868 (Gastropoda: Pulmonata: Arionidae) in Poland. Journal of Plant Protection Research 47:219-230.

Kozlowski J., Kozlowski R. J. 2011. Expansion of the invasive slug species Arion lusitanicus Mabille, 1868 (Gastropoda: Pulmonata: Stylommatophora) and dangers to garden crops - a literature review with some new data. Folia Malacologica 19: 249-258.

Noble L. R. 1992. Differentiation of large arionid slugs (Mollusca, Pulmonata) using ligula morphology. Zoologica Scripta 21: 255-263.

Nori J., Urbina-Cardona J. N., Loyola R. D., Lescano J., Leynaud G. C. 2011. Climate change and American Bullfrog invasion: What could we expect in South America? PLoS ONE 6: e25718.

Phillips S. J., Anderson R. P., Schapire R. E. 2006. Maximum entropy modeling of species geographic distributions. Ecological Modelling 190: 231-259.

Quinteiro J., Rodriguez-Castro J., Castillejo J., Iglesias-Piñeiro J., Rey-Méndez M. 2005. Phylogeny of slug species of the genus Arion: evidence of monophyly of Iberian endemics and of the existence of relict species in Pyrenean refuges. Journal of Zoological Systems 43: 139-148.

Reischütz P. L. 1984. Zum massenhaften Auftreten von Arion lusitanicus Mabille in den Jahren 1982 und 1983. Mitteilungen der. zoolischen Gesellscaft Braunau 4: 253-254.

Sax D. F., Gaines S. D., Stachowicz J. J. 2005. Species invasions - insights into ecology, evolution and biogeography. Sinauer Associates Inc., Sunderland, USA.

Shigesada N., Kawasaki K. 1997. Biological Invasions: Theory and practice. Oxford University Press, Oxford.

Tomasgård T.E.H.2005.Populasjonsdynamikk, næringspreferansar og reproduksjon/vekst hjå snilen Arion lusitanicus Mabille, 1868. "Population dynamics, food preferences, reproduction and growth in the slug Arion lusitanicus Mabille, 1868." Unpublished Candidata Scientiarum-thesis. University of Bergen, Bergen.

von Proschwitz T. 1992. Den spanska skogsnigeln Arion lusitanicus Mabille - en art i snabb spridning med människan i Sverige (In Swedish with English summary). "The Spanish slug Arion lusitanicus Mabille - an anthropochorous slug species spreading rapidly in Sweden". Göteborgs Naturhistoriska Museum Årstryck 1992: 35-42.

von Proschwitz T. 1997. Arion lusitanicus Mabille and A. rufus (L.) in Sweden: A comparison of occurrence, spread and naturalization of two alien slug species. Heldia 4: 137-138.

von Proschwitz T. 2008. Snigel - fridstörare i örtagården. Vetenskap och fakta (In Swedish). "The slug - peacebreaker in the garden." Bohusläns Museums förlag, Göteborg, Sweden. von Proschwitz T., Winge K. 1994. Iberiaskogsnegl - en art på spredning i Norge (In Norwegian). "The Iberian slug - a species expanding in Norway." Fauna 47: 195-203.

Ward D. 2007. Modelling the potential geographic distribution of invasive ant species in New Zealand. Biological Invasions 9: 723-735.

Editorial responsibility: Jussi Evertsen.

This article is open-access and distributed under the terms of the Creative Commons Attribution-Noncommercial 3.0 Unported License (http://creativecommons.org/licenses/by-nc/3.0/). This permits all non-commercial use, distribution, and reproduction in any medium, provided the original work is properly cited. 
Appendix I. Recorded distribution of Arion vulgaris in Norway. Year indicates first verified record. Source: "AA" = Arild Andersen, "SR" = Steffen Roth, "DD \& KW" = Dolmen \& Winge (1997), "BAH" = Bjørn Arild Hatteland, "TS" = Torstein Solhøy, "TH" = Trond Hofsvang, "TIV" = Thor Inge Vollan, "VF" = Vivian Felde, "JH" = John Skartveit, "S" = verified records from garden societies, "Mattilsynet" = the Norwegian Food Safety Authority.

\begin{tabular}{|c|c|c|c|c|}
\hline County & Municipality & Year & Locality & Source \\
\hline Troms & Berg & 2007 & Steinfjorden in Senja & AA \\
\hline Troms & Lervik & 2005 & Finnsnes & SR, Mattilsynet \\
\hline Nordland & Bodø & 2008 & Bodø & TS, SR \\
\hline Nordland & Brønnøy & 2007 & Trælnes, Brønnøysund & $\mathrm{AA}, \mathrm{SR}$ \\
\hline Nordland & Sømna & 2008 & & SR \\
\hline Nordland & Vefsn & 2008 & Mosjøen & $\mathrm{S}, \mathrm{SR}, \mathrm{AA}$ \\
\hline Nord-Tøndelag & Frosta & 2008 & & $\begin{array}{l}\text { Frosta municipality, County of } \\
\text { Nord-Trøndelag }\end{array}$ \\
\hline Nord-Tøndelag & Levanger & 1995 & Skogn, Nesset, Ytterøy, Levanger & DD \& KW, Mattilsynet \\
\hline Nord-Tøndelag & Namsos & 2007 & Namsos & $\mathrm{AA}$ \\
\hline Nord-Tøndelag & Steinkjer & 1995 & Steinkjer (Egge), Røysing & $\begin{array}{l}\text { DD \& KW, S, County of Nord- } \\
\text { Trøndelag, SR, TS, Steinkjer } \\
\text { municipality }\end{array}$ \\
\hline Nord-Tøndelag & Stjørdal & 1991 & Stokkberga, Stjørdal, Husbylia & DD \& KW, Mattilsynet \\
\hline Sør-Trøndelag & Agdenes & 2008 & Lensvik & S \\
\hline Sør-Trøndelag & Bjugn & 2009 & Lysøysund & $\mathrm{S}$ \\
\hline Sør-Trøndelag & Frøya & 2008 & Sistranda & Mattilsynet \\
\hline Sør-Trøndelag & Hemne & 2008 & & $\mathrm{~S}$ \\
\hline Sør-Trøndelag & Hitra & 2008 & Hitra & Mattilsynet \\
\hline Sør-Trøndelag & Meldal & 1995 & Meldal & S, DD \& KW \\
\hline Sør-Trøndelag & Melhus & 2008 & Hovin & Mattilsynet \\
\hline Sør-Trøndelag & Midtre Gauldal & 2009 & Soknesmoen in Støren & Mattilsynet \\
\hline Sør-Trøndelag & Orkdal & 2008 & Vormstad, Fannrem, Vannspeilet, Orkanger & S, SR \\
\hline Sør-Trøndelag & Rissa & 2008 & Fenstad, Stadsbygd & S \\
\hline Sør-Trøndelag & Røros & 2009 & Pinsti & Artsobservasjoner.no \\
\hline Sør-Trøndelag & Trondheim & 1995 & Trondheim, Nardo, Øya & $\mathrm{DD} \& \mathrm{KW}$ \\
\hline Sør-Trøndelag & Ørland & 1995 & Brekstad, Uthaug & SR, DD \& KW \\
\hline Møre og Romsdal & Aukra & 1994 & Aukra & $\mathrm{DD} \& \mathrm{KW}$ \\
\hline Møre og Romsdal & Aure & 1995 & Tustna, Leira & DD \& KW \\
\hline Møre og Romsdal & Eide & 2008 & & S \\
\hline Møre og Romsdal & Fræna & 1994 & Elnesvågen & DD \& KW \\
\hline Møre og Romsdal & Giske & 2010 & Valderhaug & BAH \\
\hline Møre og Romsdal & Gjemnes & 2008 & & S \\
\hline Møre og Romsdal & Haram & 2009 & & $\begin{array}{l}\text { Vatne og Tennfjord Garden } \\
\text { Society }\end{array}$ \\
\hline Møre og Romsdal & Hareid & 2008 & Hareid & SR \\
\hline Møre og Romsdal & Kristiansund & 2012 & Kristiansund & $\mathrm{BAH}$ \\
\hline Møre og Romsdal & Midsund & 2008 & & S \\
\hline Møre og Romsdal & Molde & 1988 & Bolsøy, Kleive & DD \& KW, TS, BAH, SR \\
\hline Møre og Romsdal & Nesset & 2012 & Eidsvåg & $\mathrm{BAH}$ \\
\hline Møre og Romsdal & Rauma & 2008 & Isfjorden & SR \\
\hline Møre og Romsdal & Sandøy & 2008 & Finnøya & Mattilsynet \\
\hline Møre og Romsdal & Skodje & 2008 & Valle & SR \\
\hline
\end{tabular}


Appendix I. Continued

\begin{tabular}{|c|c|c|c|c|}
\hline County & Municipality & Year & Locality & Source \\
\hline Møre og Romsdal & Sula & 2010 & Leirvåg & BAH \\
\hline Møre og Romsdal & Sunndal & 2012 & Sunndalsøra & $\mathrm{BAH}$ \\
\hline Møre og Romsdal & Surnadal & 2009 & Stangvik & S \\
\hline Møre og Romsdal & Tingvoll & 2007 & Tingvoll, Torjulsvågen & $\mathrm{TS}, \mathrm{BAH}$ \\
\hline Møre og Romsdal & Ulstein & 2008 & Ullsteinvik & SR \\
\hline Møre og Romsdal & Vestnes & 2008 & & $\mathrm{~S}$ \\
\hline Møre og Romsdal & Volda & 2010 & Volda & $\mathrm{BAH}$ \\
\hline Møre og Romsdal & Ørskog & 2010 & Sjøholt & $\mathrm{BAH}$ \\
\hline Møre og Romsdal & Ørsta & 2010 & Ørsta & BAH \\
\hline Møre og Romsdal & Ålesund & 2008 & Ålesund, Spjelkavik & S, SR \\
\hline Sogn og Fjordane & Askvoll & 2008 & Askvoll & $\mathrm{S}$ \\
\hline Sogn og Fjordane & Balestrand & 2010 & Balestrand & $\mathrm{BAH}$ \\
\hline Sogn og Fjordane & Eid & 1995 & Nordfjoreid & $\mathrm{SR}, \mathrm{DD} \& \mathrm{KW}, \mathrm{S}$ \\
\hline Sogn og Fjordane & Flora & 2008 & Florø & S, Florø municipality \\
\hline Sogn og Fjordane & Førde & 2008 & Førde & SR \\
\hline Sogn og Fjordane & Gloppen & 2008 & Vereide, Sandane & $\mathrm{S}$ \\
\hline Sogn og Fjordane & Gulen & 2010 & Eivindvik & BAH \\
\hline Sogn og Fjordane & Høyanger & 2008 & & $\mathrm{~S}$ \\
\hline Sogn og Fjordane & Jølster & 2008 & Skei & SR \\
\hline Sogn og Fjordane & Leikanger & 2010 & Leikanger & $\mathrm{BAH}$ \\
\hline Sogn og Fjordane & Luster & 2008 & Gaupne & $\mathrm{VF}$ \\
\hline Sogn og Fjordane & Lærdal & 2008 & Lærdalsøyri & $\mathrm{S}$ \\
\hline Sogn og Fjordane & Sogndal & 2004 & Sogndal & $\mathrm{TS}$ \\
\hline Sogn og Fjordane & Stryn & 2008 & Visnes & $\mathrm{S}$ \\
\hline Sogn og Fjordane & Vågsøy & 2008 & Måløy & SR \\
\hline Hordaland & Askøy & 2006 & Øvre Kleppe, Ask & BAH \\
\hline Hordaland & Austevoll & 2008 & Helmark & Mattilsynet \\
\hline Hordaland & Austrheim & 2008 & & Mattilsynet \\
\hline Hordaland & Bergen & 1992 & $\begin{array}{l}\text { Morvik, Nordås, Nyborg, Laksevåg, Åsane, } \\
\text { Landås, Fana }\end{array}$ & DD \& KW, TS, BAH, S \\
\hline Hordaland & Bømlo & 2002 & Svortland, Moster & SR, TS \\
\hline Hordaland & Eidfjord & 2008 & & Mattilsynet \\
\hline Hordaland & Etne & 2008 & & Mattilsynet \\
\hline Hordaland & Fitjar & 2000 & Fitjar & TS, SR \\
\hline Hordaland & Fjell & 1995 & Sotra & DD \& KW \\
\hline Hordaland & Fusa & 2008 & & $\mathrm{~S}$ \\
\hline Hordaland & Granvin & 2008 & Granvin bruk and harbour area & Mattilsynet \\
\hline Hordaland & Jondal & 2008 & & $\mathrm{~S}, \mathrm{TS}$ \\
\hline Hordaland & Kvam & 2006 & $\begin{array}{l}\text { Tangerås, Øystese, Strandebarm, Nordheim, } \\
\text { Nes }\end{array}$ & S, TS \\
\hline Hordaland & Kvinnherad & 2008 & Opsanger, Kaldestad & S \\
\hline Hordaland & Lindås & 1995 & & $\mathrm{~S}, \mathrm{DD} \& \mathrm{KW}$ \\
\hline Hordaland & Meland & 2006 & Frekhaug, southern part of the municipality & BAH, S \\
\hline Hordaland & Odda & 2008 & & $\mathrm{~S}$ \\
\hline Hordaland & Os & 1995 & Haugsbrotet & $\mathrm{TS}$ \\
\hline
\end{tabular}


Appendix I. Continued.

\begin{tabular}{|c|c|c|c|c|}
\hline County & Municipality & Year & Locality & Source \\
\hline Hordaland & Osterøy & 2008 & Haus, Ljonevåg, Valestrandfossen & Mattilsynet \\
\hline Hordaland & Radøy & 2008 & Bøvågen, Manger, Austmarka & $\mathrm{S}$ \\
\hline Hordaland & Samnanger & 2008 & & Mattilsynet \\
\hline Hordaland & Stord & 1993 & Leirvik & DD \& KW, TS \\
\hline Hordaland & Sund & 2008 & & $\mathrm{~S}$ \\
\hline Hordaland & Sveio & 2008 & $\begin{array}{l}\text { Førde, Rød, Tveita, Haukås, Bjelland, Sveio, } \\
\text { Tveit }\end{array}$ & S \\
\hline Hordaland & Tysnes & 2008 & & $\mathrm{~S}$ \\
\hline Hordaland & Ullensvang & 2006 & West part, Lofthus & S, TS, BAH \\
\hline Hordaland & Ulvik & 2008 & Ulvik & $\mathrm{S}$ \\
\hline Hordaland & Voss & 2004 & Voss & TS, S \\
\hline Hordaland & Øygarden & 2006 & Rongøyna & $\mathrm{BAH}$ \\
\hline Rogaland & Bjerkreim & 2010 & Vikeså & BAH \\
\hline Rogaland & Finnøy & 1994 & Ladstein & JS, SR \\
\hline Rogaland & Forsand & 2008 & Forsand, Rossavik & $\mathrm{S}$ \\
\hline Rogaland & Gjesdal & 2008 & Dirdal, Oltedal & SR \\
\hline Rogaland & Haugesund & 1996 & Haugesund & $\mathrm{TS}$ \\
\hline Rogaland & Hjelmeland & 2010 & Hjelmelandsvågen, Fister & $\mathrm{BAH}$ \\
\hline Rogaland & Karmøy & 2010 & Kopervik & BAH \\
\hline Rogaland & Klepp & 1995 & Kleppe & $\mathrm{DD} \& \mathrm{KW}, \mathrm{BAH}$ \\
\hline Rogaland & Kvitsøy & 2010 & Kvitsøy & BAH \\
\hline Rogaland & Randaberg & 1995 & Randaberg & DD \& KW \\
\hline Rogaland & Rennesøy & 2008 & Hanasand & SR \\
\hline Rogaland & Sandnes & 2008 & Høle, Sandnes & $\mathrm{SR}, \mathrm{BAH}$ \\
\hline Rogaland & Sola & 2008 & Vigdel & BAH \\
\hline Rogaland & Stavanger & 1995 & Stavanger, Hafsfjord, Hunsvåg, Storhaug & DD \& KW, SR \\
\hline Rogaland & Strand & 2010 & Tau, Jørpeland & BAH \\
\hline Rogaland & Time & 1995 & Bryne & DD \& KW \\
\hline Rogaland & Tysvær & 2010 & Førre & $\mathrm{BAH}$ \\
\hline Rogaland & Utsira & 2008 & & Utsira municipality \\
\hline Rogaland & Vindafjord & 2010 & Ølen, Øvre Vats & BAH \\
\hline Vest-Agder & Audnedal & 2008 & Konsmo & SR \\
\hline Vest-Agder & Flekkefjord & 2010 & Flekkefjord & SR, BAH \\
\hline Vest-Agder & Kristiansand & 2009 & Kristiansand, Flekkerøy & DD \& KW -Uncertain, SR \\
\hline Vest-Agder & Lindesnes & 2008 & Fasseland & SR \\
\hline Vest-Agder & Mandal & 2008 & Holum & SR \\
\hline Vest-Agder & Marnadal & 2008 & Marnadal-Manneskaret & SR \\
\hline Vest-Agder & Søgne & 2009 & Søgne & TIV \\
\hline Aust-Agder & Arendal & 2007 & Hisøy, Arendal, Tromøy & SR, BAH, TS \\
\hline Aust-Agder & Froland & 2012 & Osedalen & $\mathrm{TS}$ \\
\hline Aust-Agder & Gjerstad & 2012 & Moen & TS \\
\hline Aust-Agder & Grimstad & 2010 & Fevik, Grimstad & SR, TS \\
\hline Aust-Agder & Risør & 2010 & Risør & SR, BAH \\
\hline Aust-Agder & Tvedestrand & 2009 & Tvedestrand & $\mathrm{TS}$ \\
\hline Oslo & Oslo & 1995 & Sogn kolonihage & $\mathrm{DD} \& \mathrm{KW}, \mathrm{AA}$ \\
\hline
\end{tabular}


Appendix I. Continued

\begin{tabular}{|c|c|c|c|c|}
\hline County & Municipality & Year & Locality & Source \\
\hline$\emptyset$ stfold & Askim & 2009 & Askim & $\mathrm{AA}$ \\
\hline Østfold & Eidsberg & 2009 & Mysen & AA \\
\hline Østfold & Fredrikstad & 1988 & Kråkerøy & DD \& KW \\
\hline Østfold & Halden & 1995 & Halden & DD \& KW \\
\hline Østfold & Hobøl & 2010 & Knapstad & $\mathrm{AA}$ \\
\hline Østfold & Hvaler & 2009 & Papperhavn & AA \\
\hline Østfold & Marker & 2010 & Sletta & AA \\
\hline Østfold & Moss & 2009 & & AA \\
\hline Østfold & Rakkestad & 2009 & Gabestad gård & $\mathrm{AA}$ \\
\hline Østfold & Rygge & 2009 & Halmstad & AA \\
\hline Østfold & Råde & 2009 & Stenrødgård, Karlsrud & $\mathrm{AA}$ \\
\hline Østfold & Skiptvet & 2010 & Skiptvet & $\mathrm{AA}$ \\
\hline Østfold & Spydeberg & 2007 & Spydeberg & $\mathrm{AA}$ \\
\hline Østfold & Trøgstad & 2009 & Trøgstad & $\mathrm{AA}$ \\
\hline Østfold & Våler & 2009 & Folkestadfeltet & AA \\
\hline Akershus & Asker & 1996 & Blakstad, Asker, Vøyenenga, Vollen & $\mathrm{DD} \& \mathrm{KW}, \mathrm{AA}$ \\
\hline Akershus & Bærum & 1995 & Bekkestua, Slependen & $\mathrm{DD} \& \mathrm{KW}, \mathrm{AA}$ \\
\hline Akershus & Enebakk & 1996 & Ytre Enebakk & DD \& KW \\
\hline Akershus & Fet & 2009 & Fetsund & $\mathrm{AA}$ \\
\hline Akershus & Frogn & 2006 & Drøbak & AA \\
\hline Akershus & Nes & 2010 & Auli & AA \\
\hline Akershus & Nesodden & 2000 & Nesoddtangen & AA \\
\hline Akershus & Oppegård & 2009 & Kolbotntjern & AA \\
\hline Akershus & Rælingen & 2003 & Rælingen & AA \\
\hline Akershus & Skedsmo & 2007 & Strømmen & AA \\
\hline Akershus & Sørum & 2005 & Sørumsand & AA \\
\hline Akershus & Ski & 2010 & Kråkstad & AA \\
\hline Akershus & Vestby & 1995 & Son & DD \& KW \\
\hline Akershus & Ås & 1995 & Ås & $\mathrm{DD} \& \mathrm{KW}, \mathrm{AA}$ \\
\hline Hedmark & Hamar & 2007 & Hamar & AA \\
\hline Hedmark & Kongsvinger & 2005 & Kongsvinger & $\mathrm{AA}$ \\
\hline Hedmark & Løten & 2009 & Løten & AA \\
\hline Hedmark & Stange & 2008 & Espa & $\mathrm{AA}$ \\
\hline Oppland & Gjøvik & 2005 & Gjøvik & AA \\
\hline Oppland & Vestre Toten & 2010 & Raufoss & AA \\
\hline Buskerud & Drammen & 1995 & Drammen & DD \& KW \\
\hline Buskerud & Hole & 2010 & Krokleiva & AA \\
\hline Buskerud & Hurum & 2009 & Sætre & AA \\
\hline Buskerud & Lier & 2007 & Børreshaugen, Lier & AA \\
\hline Buskerud & Modum & 2001 & Vikersund & AA \\
\hline Buskerud & Nedre Eiker & 2006 & & AA \\
\hline Buskerud & Ringerike & 2002 & Heradsbygd, Hønefoss & AA \\
\hline Buskerud & Røyken & 2011 & Spikkestad & AA \\
\hline Buskerud & Øvre Eiker & 2010 & Skotselv & AA \\
\hline Vestfold & Holmestrand & 2009 & Holmestrand & $\mathrm{AA}$ \\
\hline
\end{tabular}


Appendix I. Continued

\begin{tabular}{lllll}
\hline County & Municipality & Year & Locality & Source \\
\hline Vestfold & Horten & 2007 & Strandparken, Horten & AA \\
Vestfold & Larvik & 2009 & Stavern & AA \\
Vestfold & Lardal & 2012 & Svarstad & AA \\
Vestfold & Nøtterøy & 2000 & Torød & AA \\
Vestfold & Re & 2008 & Revetal & AA \\
Vestfold & Sande & 2009 & Skjervik & AA \\
Vestfold & Sandefjord & 1995 & Sandefjord & DD \& KW \\
Vestfold & Stokke & 2008 & Stokke, Gjennestad & AA, TS \\
Vestfold & Svelvik & 2009 & Svelvikveien 417 & AA \\
Vestfold & Tjøme & 2008 & & AA, TS \\
Vestfold & Tønsberg & 2011 & Solvang, Eik & AA \\
Telemark & Bamble & 1988 & Langesund, Stathelle & DD \& KW \\
Telemark & Drangedal & 2006 & Prestestranda, Drangedal & AA, SR \\
Telemark & Fyresdal & 2008 & Fyresdal & AA \\
Telemark & Kragerø & 1992 & Kragerø & DD \& KW \\
Telemark & Nome & 1999 & Lunde & AA \\
Telemark & Notodden & 2005 & Notodden & AA \\
Telemark & Porsgrunn & 1991 & Brevik & DD \& KW \\
Telemark & Seljord & 2003 & Seljord & AA \\
Telemark & Skien & 1992 & Skien, Stromdalskåsa & DD \& KW \\
Telemark & Vinje & 2008 & Amot & AA \\
\hline
\end{tabular}


Appendix 2. Unverified distribution of Arion vulgaris in Norway. "U" = uncertain record, "P" = probable distribution. "DD \& KW" = Dolmen \& Winge (1997), "TH" = Trond Hofsvang, "Mattilsynet" = the Norwegian Food Safety Authority, "NRK" = Norwegian Broadcasting Corporation.

\begin{tabular}{llllll}
\hline County & Municipality & Year & Locality & Status & Source \\
\hline Finnmark & Kautokeino & 2012 & Kautokeino & $\mathrm{U}$ & AA \\
Troms & Tromsø & 2007 & Tromsø & $\mathrm{U}$ & NRK, TH \\
Nordland & Alstahaug & 2009 & & $\mathrm{U}$ & Alstahaug Garden Society \\
Nordland & Nesna & 2009 & & $\mathrm{U}$ & Nesna Garden Society \\
Nordland & Rana & 2009 & Utskarpen & $\mathrm{U}$ & Rana Garden Society \\
Sør-Trøndelag & Malvik & 2009 & Hommelvik & $\mathrm{P}$ & Malvik Garden Society \\
Møre og Romsdal & Stranda & 1995 & Stranda & $\mathrm{U}$ & DD \& KW \\
Møre og Romsdal & Sykkylven & 2009 & Fauske, Blindheim, Sykkylven, & P & Sykkylven Garden \\
Sogn og Fjordane & Gaular & 2009 & Sande & $\mathrm{P}$ & Society \\
Sogn og Fjordane & Hornindal & 2010 & Grodås & $\mathrm{P}$ & Gaular Garden Society \\
Sogn og Fjordane & Naustdal & 2010 & Naustdal & $\mathrm{P}$ & Nornindal Garden Society \\
Hordaland & Modalen & 2008 & Mo & $\mathrm{U}$ & Mattilsynet, Modalen \\
Rogaland & Eigersund & 2008 & Eigerøya, Egersund & $\mathrm{P}$ & Garden Society \\
Rogaland & Hå & 2009 & & $\mathrm{P}$ & Unknown \\
Rogaland & Sokndal & 2010 & Hauge i Dalane & $\mathrm{P}$ & Sokndal Garden Society \\
Rogaland & Suldal & 2009 & Strand & $\mathrm{P}$ & Suldal Garden Society \\
Vest-Agder & Kvinesdal & 2010 & Feda & P & Kvinesdal Garden Society \\
Vest-Agder & Sirdal & 2009 & Tonstad & P & Sirdal Garden Society \\
Vest-Agder & Songdalen & 2010 & Nodeland & P & Songdalen Garden \\
Vest-Agder & Vennesla & 2009 & Vennesla & P & Vennesla Garden Society \\
Aust-Agder & Lillesand & 2010 & & $\mathrm{P}$ & Aust-Agder Garden \\
Øsfold & Sarspborg & 1995 & Sarpsborg, Hannestad, Greåker & $\mathrm{U}$ & DD \& KW \\
Hedmark & Elverum & 2005 & Elverum & $\mathrm{U}$ & AA \\
\hline
\end{tabular}

